\title{
CORRIGENDUM
}

\section{Inhibition of tumor growth and metastasis in vitro and in vivo by targeting macrophage migration inhibitory factor in human neuroblastomas}

\author{
Y Ren, HM Chan, Y Xie, YX Chen, W Li, GP Jiang, Q Liu, A Meinhardt and PKH Tam
}

Oncogene (2006) 25, 7224. doi:10.1038/sj.onc.1210005

\section{Correction to:}

Oncogene (2006) 25, 3501-3508. doi:10.1038/sj.onc.1209395; published online 30 January 2006

Part of Figure 1 of this paper was previously published as Figure 2a of the following paper: Fan J, Chen Y, Chan HM, Tam PKH and Ren Y. (2005). Removing intensity effects and identifying significant genes for Affymetrix arrays in macrophage migration inhibitory factor-suppressed neuroblastoma cells. Proc Natl Acad Sci USA 102: 17751-17756.

The authors would like to apologize for not citing this originally.

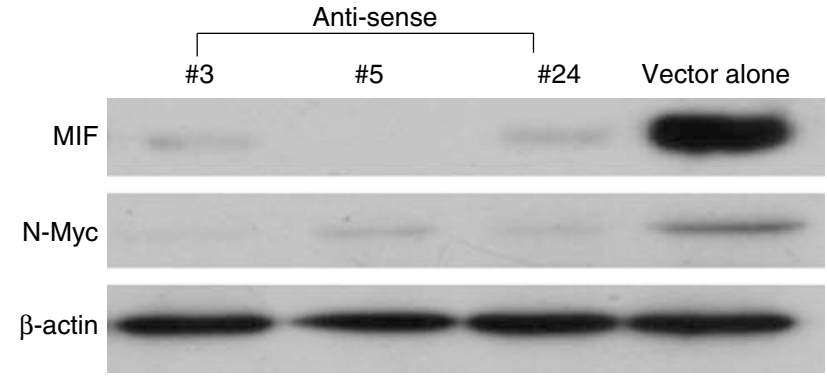

Copyright (2005) National Academy of Sciences, USA

\section{ERRATUM}

\section{Antileukemic roles of human phospholipid scramblase 1 gene, evidence from inducible PLSCR1-expressing leukemic cells}

\author{
Y Huang, Q Zhao, C-X Zhou, Z-M Gu, D Li, H-Z Xu, T Wiedmer, PJ Sims, K-W Zhao
} and G-Q Chen

Oncogene (2006) 25, 7224. doi:10.1038/sj.onc.1210082

Correction to: Oncogene (2006) 25: 6618-6627. doi:10.1038/sj.onc.1209677

Due to a typesetting error, on page 6618 Dr $T$ Wiedmer's name was omitted from the list of authors.
Dr Wiedmer is affiliated with the Department of Molecular and Experimental Medicine, The Scripps Research Institute, La Jolla, CA, USA. 